\title{
RATE OF DEVELOPMENT, THRESHOLD (ZERO) OF DEVELOPMENT AND THERMAL UNITS FOR DIFFERENT STAGES OF MEALYBUG, Icerya seychellarum (WESTWOOD) AT DIFFERENT DEGREES OF TEMPERATURE. Abdel Aleem, R.Y. Department of Economic Entomology \& Pesticides, Fac. Of Agric., Cairo Univ., Giza- Egypt
}

\begin{abstract}
Different biological features of Icerya seychellarum was studied under four different degrees of constant temperature on mango seedlings, Mangifera indica. Rate of development was 8.0, 2.3 and 1.9 days at $15^{\circ} \mathrm{C}$ for egg, nymphal and adult stages, respectively, while it was $23.8,40$ and 3.9 days for the same stages, at $33^{\circ} \mathrm{C}$. Hypothetical threshold (zero) of development was 9.2, 10.4 and $12.4^{\circ} \mathrm{C}$ for egg, nymphal and adult stages, respectively. Mean thermal units was 85.5, 429.3 and 384.3 degree/ days for egg, nymphal and adult stages, respectively.
\end{abstract}

\section{INTRODUCTION}

The Seychelles fluted sacle, Icerya seychellarum is a polyphagous phloem-feeding. It was introduced to Egypt on banana fruits (Brizi, 1935). This species was first recorded in Egypt by Ezz and Samhan (1965)on five ornamental plant species at Suez Governorate, since that time it has spread rapidly and infests many economic horticulatural plants. Recently, the range of host plants of I.seychellarum in Egypt includes at least 44 species belonging to 25 families (Assem, et al.,1991). This small soft bodied mealybug feeds on the underside of leaves sucking out plant sap. At high infestation levels, serious damage resulting in early leaf drop and yield reduction is caused by this insect. Moreover, high populations of $I$. seychellarum can reduce the vigor of the plant, making it susceptible to other pests (Osman, 2005).

\section{MATERIALS AND METHODS}

The experiments were carried out under four different degrees of temperature, $\left(15,21,27\right.$ and $\left.33^{\circ} \mathrm{C}\right)$. To study the life cycle of I. seychellarum under different conditions of temperatures, highly infested mango leaves were selected in the field and transferred to another healthy mango seedlings transplanted in pots in the laboratory Newly laid eggs were isolated from the ovipositing females and the ovisacs were carefully kept in glass cages $2 \times 3 \mathrm{~cm}$, covered with muslin tissues and incubated at four degrees of temperatures using special incubator till hatching and the incubation periods were recorded.

To study the duration of nymphal stage, newly hatched crawlers were observed daily for detecting and recording any newly morphological changes 
till the emergence of adult females and the periods of this stage was recorded. For studying the duration of adult females, the periods from the day of attaining these nymphs to the adult female stages till the death of these females were recorded.

Rate of development of each stage was calculated from the equation according to Stinner et al. (1974).

Rate of development $=\frac{1}{t} \times 100$

Where, $\mathrm{t}$ is the duration of the stage in days.

Threshold (zero) of development for each stage was determined according to Alrouechdi (1986).

Threshold of development $=\mathrm{T}_{1}-\frac{P_{2}\left(T_{2}-T_{1}\right)}{P_{1}-P_{2}}$

Where, $P_{1}=$ Period of insect development at $\left(T_{1}\right)$ temperature .

$P_{2}=$ Period of insect development at $\left(T_{2}\right)$ temperature.

The thermal units required for each stage were represented as degree/ days $\left(D^{\circ}\right)$ as the fraction of time spent in each stage are based on this threshold according to Wilma, et al. (1994).

Thermal units $=\mathrm{Dt}(\mathrm{Td}-\mathrm{Tt})$

Where, $\mathrm{Dt}=$ duration of the stage

$\mathrm{Td}=$ average temperature during development of the stage.

$\mathrm{Tt}=$ Threshold (zero ) temperature of development of the stage.

\section{RESULTS And DISCUSSIONS}

\section{Egg stage :}

Rate of development, threshold of development and thermal units required for Egg stage are summarized in table (1) and graphically illustrated in Fig. (1). These results revealed that the rates of development were relatively slow at lower temperatures $\left(8.0\right.$ days at $\left.15^{\circ} \mathrm{C}\right)$, while it was faster at higher temperature $\left(23-9\right.$ days at $\left.33^{\circ} \mathrm{C}\right)$. It could be concluded that tolerant temperature zone for egg stage of I.seychellarum ranged between 27 and $33^{\circ} \mathrm{C}$., the hypothetical threshold (zero) of development for egg stage was found to be $9.2^{\circ} \mathrm{C}$. This value was detected by applying results obtained for incubation period ranging between 15.0 and $33^{\circ} \mathrm{C}$. Mean Thermal units required for completing egg development was 85.5 degree/days.

\section{Nymphal stage:}

Results of the rate of development, threshold and thermal units required for nymphal stage are given in Table (1) and graphically illustrated in Fig. (1) . These results indicate that rates of development were relatively slow at lower temperature being faster at higher temperatures. These results were 2.3 at $15^{\circ} \mathrm{C}$ and 4.0 at $33.0^{\circ} \mathrm{C}$. The threshold (zero) of development was found to be $10.4^{\circ} \mathrm{C}$. Mean thermal units for completing this stage was 429.3 degree/days. 
Adult female stage :

Results in table (1) and fig(1) show that rates of development were at their minimum at lower temperature and their maximum at higher temperature being $1.9,2.8,2.6$ and 3.9 days at $15,21,27$ and $33^{\circ} \mathrm{C}$, respectively. The threshold (zero) of development was 12.4 for adult female, while the mean thermal units needed for completing this stage was 384.3 degree/ days . Results obtained are in harmony with those found by Osman (2005) who illustrated that the adult period ranged between 35 and 134 days when it reared on mulberry seedlings at laboratory conditions of $25-37^{\circ} \mathrm{C}$ and 44.5 $54.5 \%$ R.H , while Abdel Aleem (2003) found that the rate of development of egg, larval, pre-pupal, pupal and adult female stages of Phylotocnistis citrella was $13.3,3.5,22.7,2.9$ and 3.9 days at $15^{\circ} \mathrm{C}$, respectively, while it was 33.3 , $25,100,19.2$ and 20 days at $30^{\circ} \mathrm{C}$ for the same stages. Mean thermal units was $62.15,71.7,27.1,74.7$ and 112.6 degrees/days for egg, larval, prepupal, pupal and adult stages, respectively.

Table (1): Rate of development (in days), Threshold (zero) of development ${ }^{\circ} \mathrm{C}$ and thermal units (degree/ days) for different developmental stages of I.seychellarum at four different degrees of temperature.

\begin{tabular}{|c|c|c|c|c|c|c|c|c|}
\hline \multirow[t]{2}{*}{ Ter } & \multirow{2}{*}{\begin{tabular}{|c|} 
Egg \\
stage \\
Rate of \\
devel.
\end{tabular}} & \multicolumn{2}{|c|}{ Nymphal stage } & \multicolumn{2}{|c|}{ Adult Female } & \multicolumn{3}{|c|}{ Life span } \\
\hline & & \begin{tabular}{|c|} 
Thermal \\
units
\end{tabular} & $\begin{array}{c}\text { Rate of } \\
\text { devel. }\end{array}$ & $\begin{array}{c}\text { Thermal } \\
\text { units }\end{array}$ & \begin{tabular}{|c|}
$\begin{array}{c}\text { Rate of } \\
\text { devel. }\end{array}$ \\
\end{tabular} & $\begin{array}{c}\text { Thermal } \\
\text { units }\end{array}$ & $\begin{array}{l}\text { Rate o } \\
\text { devel. }\end{array}$ & $\begin{array}{l}\text { Therma } \\
\text { I units }\end{array}$ \\
\hline 15 & 8.0 & 60.0 & 2.3 & 214.0 & 1.9 & 166.7 & 12.2 & 440.7 \\
\hline 21 & 10.2 & 95.6 & 3.1 & 420.8 & 2.8 & 304.4 & 16.1 & 820.8 \\
\hline 27 & 13.0 & 92.4 & 3.0 & 513.0 & 2.6 & 534.5 & 18.6 & 1139.9 \\
\hline 33 & 23.9 & 94.1 & 4.0 & 569.5 & 3.9 & 531.5 & 31.7 & 1195.1 \\
\hline $\begin{array}{l}\text { Mean of } \\
\text { thermal } \\
\text { units }\end{array}$ & & 85.5 & & 429.3 & & 384.3 & & 898.2 \\
\hline $\begin{array}{ll}\text { Zero } & \text { of } \\
\text { devel. } & \\
\end{array}$ & & .2 & & 0.4 & & 2.4 & & 0.7 \\
\hline
\end{tabular}

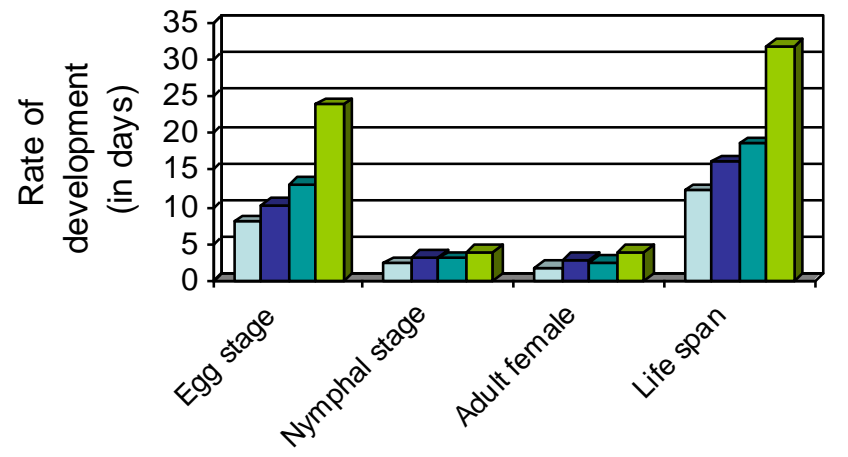

Fig.(1) : Rate of development for different stages of I.seychellarum at four different degrees of temperature. 


\section{REFERENCES}

Abdel Aleem , R.Y ( 2003) : Rate of development, thermal units and threshold (zero) of development for different developmental stages of citrus leafminer ( CLM). Phyllocnistis citrella Stainton at four different degrees of temperature. $1^{\text {st }}$ Conf, on farm Integr. Pest Manag. Fayoum, Fac. of Agric, 19 Feb.

Alrouechdi, K.S(1986): Effect of physical factors on insects. 436pp. Fac. Agric., Damascus Univ., Syria.

Assem , S.M.; Z.K. Mohamed Abd E.A Elwan (1991) : Studies on the host plants range of Icerya sychellarum . $4^{\text {th }}$ Arab Congress of Plant Protection Cairo 1-5 Dec.

Birzi, A. (1935) : Legislative and administrative measures international. Bull. Of Plant protection 9:58-76.

Ezz, A.I., and M.A. Samhan ( 1965): A margarodid new to UAR (Homoptera, Coccoidae). Agric. Res. Rev., 26(3): 116.

Osman, E.A . ( 2005): Studies on some homopterous insect pests infesting mulberry trees in relation with Bombyx mori silk production. Ph.D. Thesis. Fac.Agric. Cairo, Univ. Egypt.

Stinner, R.E; A.P. Gutierrez and G.P. Butler ( 1974) : An algorithm for temperature dependent growth rate simulation. Canadian Entomologist, 106:519-524.

Wilma , G.G; J.H. Giliomree and K.H. Pringle (1994): Life history and life tables of western flower Thrips. Frankliniella. occidentalis on English cucumbers. Bull. of Entomol. Res., 84: 219-224.

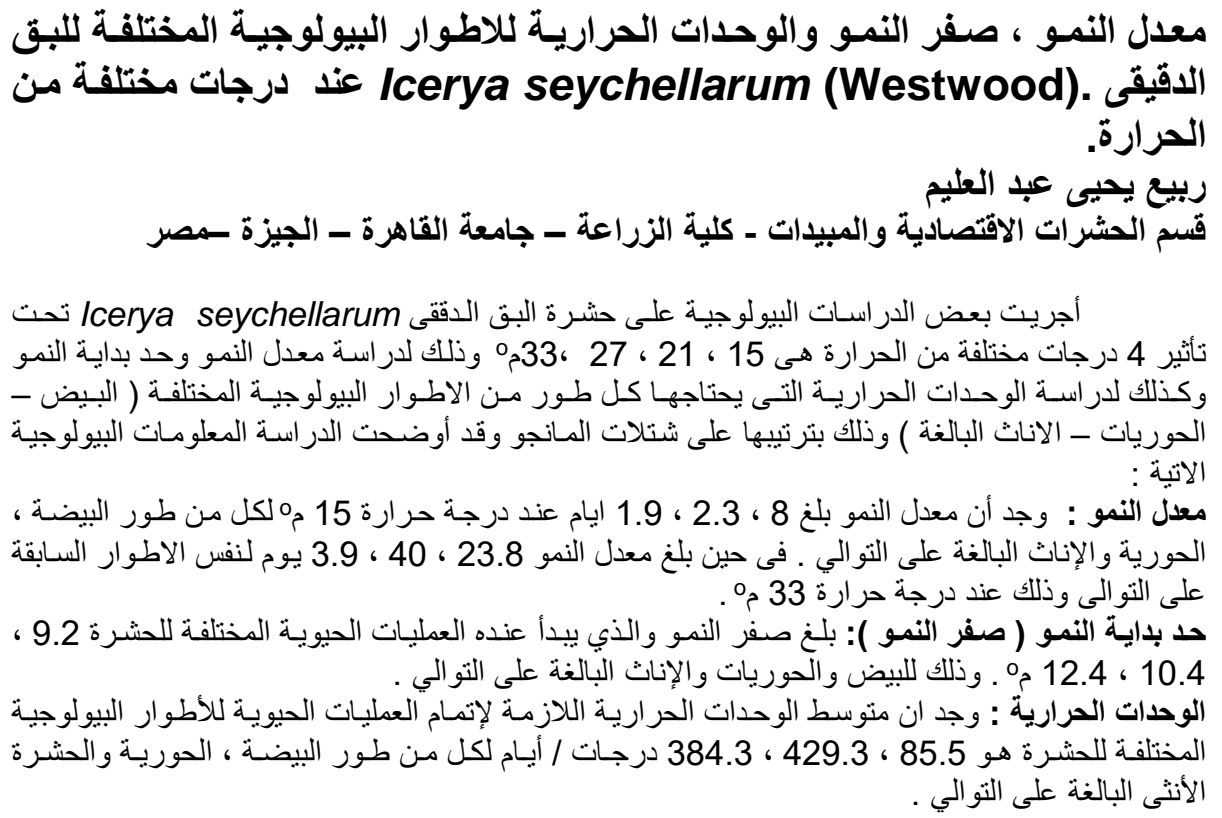

